\title{
Entrepreneurship in Greece: A Way Out of the Crisis or a Dive In?
}

\author{
Panagiotis Kotsios $^{1, *}$ \& Vasilios Mitsios ${ }^{2}$ \\ ${ }^{1}$ Technological Educational Institute of Larissa, Larissa, 41110, Greece \\ ${ }^{2} 83 B$ Kl. Patera, Larissa, 41334, Greece \\ *Corresponding author: Tel: 30-698-385-2592Ｅ-mail: panayotiskotsios@gmail.com
}

Received: January 25, 2013 Accepted: February 21, 2013 Published: March 15, 2013

doi:10.5296/rae.v5i1.3142ＵRL: http://dx.doi.org/10.5296/rae.v5i1.3142

\begin{abstract}
The goal of the current article is to examine the status and role of entrepreneurship in the Greek economy. It presents data on entrepreneurship and business demographic data as size classes, employment, value added and business failure. It also presents data on the barriers met by Greek enterprises. The final conclusion is that entrepreneurship, and especially SMEs, do play a vital role in Greek economy, but business prospects at the moment are not very good. There is an urgent need for political and economic reform, in order to support SMEs' operation and secure their valuable contribution to economy.
\end{abstract}

Keywords: entrepreneurship; Greece; business statistics; barriers; SMEs 


\section{Introduction}

The goal of the current article is to examine the status of entrepreneurship in Greece and its contribution to the economy. It presents data on entrepreneurship and business demographic data as size classes employment, value added, business failure and barriers met by Greek enterprises. These data come from multiple sources as the Global Entrepreneurship Monitor (GEM), the Organization of Economic Cooperation and Development (OECD), the European Statistical Agency (Eurostat), the World Bank and various domestic public and private organizations. In order to have a better insight on the role of entrepreneurship in economic growth, the data are presented in comparison with other European countries. Based on the findings, a set of policy recommendations is provided in the end.

\section{Literature Review}

Entrepreneurship is a multifaceted phenomenon that cuts across many disciplinary boundaries. Studies falling under the rubric of "entrepreneurship" have pursued a wide range of purposes and objectives, asked different questions and adopted different units of analysis, theoretical perspectives and methodologies (Low \& Mac Millan, 1988). This diversity is reflected in the many and varied definitions of entrepreneurship (Hebert \& Link, 1988). Schumpeter (1934) defined entrepreneurship as the carrying out of new combinations and innovations, while Knight's (1921) definition focused on the ability to predict the future successfully and to manage the market's uncertainty. On the other hand, Leibenstein (1978) argued that entrepreneurship is the ability to work smarter and harder than the competitors. Kirzner's (1973) concept was closely linked to the ability to correctly anticipate where the next market imperfections and imbalances will be. Accordingly, Cole (1968) defined entrepreneurship as purposeful activity to initiate, maintain, and develop a profit-oriented business. Stevenson et al (1985) suggested that entrepreneurship is being driven by perception of opportunity, rather than resources currently controlled. Similarly, Gartner (1985) defined entrepreneurship simply as the creation of new organizations. The problem with these definitions, is that though each captures an aspect of entrepreneurship, none captures the whole picture. Nowadays, according to Acs et al (2004) entrepreneurship has been placed as the missing link between investment in knowledge and economic growth.

Entrepreneurship is increasingly becoming recognized as a key factor contributing to economic growth (Holcombe, 1998). The finding that increased entrepreneurial activity leads to greater economic growth is now well founded at both the national and local level (Kreft \& Sobel, 2005). Reynolds et al (1999) have argued that a country's level of entrepreneurial activity explains a significant portion of the differences in national economic growth rates. According to Henderson (2002), entrepreneurs significantly impact local economies by fostering job creation, increasing wealth and incomes, and ultimately helping to connect local economies to the larger, global economy. In the same manner, Minniti (1999) claims that the entrepreneurs are the catalysts for economic growth, since they have the ability to promote the creation of new ideas and new market formations. 
The last two decades have witnessed a wealth of studies analyzing the determinants of entrepreneurship and some of these studies are theoretical (Holmes et al, 1990), while others are empirical (Evans et al, 1989). For instance, Acs \& Varga (2005) studied eleven countries and found that entrepreneurship has a positive significant effect on economic development.

However, entrepreneurship has not found a proper place in mainstream empirical economic research on the sources of economic growth (Wong \& Autio, 2005). Although many researches have been conducted theoretically and descriptively on how entrepreneurship affects the economy (Porter, 1990; Lumpkin \& Dess, 1996), there is lack of evidence based on empirical data. This is partially due to the difficulty in defining the role of the entrepreneur and formalizing its measurement for empirical modelling. Wennekers \& Thurik (1999) synthesized these disparate strands of the literature to construct an operational framework linking entrepreneurship and economic growth. They tried to highlight the multiple role of the entrepreneur, beyond that of the innovator, that includes not only something new but also a new entry in the market.

Similarly, Schmitz \& James (1989) conceptualised a model motivated by the endogenous growth models as developed by Romer (1986), who concluded that increasing levels of entrepreneurship in an economy generates additional input in the economy. In the same manner, Schumpeter (1934) first claimed that entrepreneurship causes economic growth by allowing the means of production in a society to be used in newer and more efficient combinations. A more recent argument for treating entrepreneurship as an independent factor of economic growth can be found in Audretsch \& Keilbach (2004), who examined the exact nature of the relationship between knowledge and economic growth. They argue that a distinction should be made between the general body of publicly available knowledge and economic knowledge - a subset of knowledge from the general body which businesses have found a way to use profitably. The authors actually state that general knowledge is converted into economic knowledge by the efforts of entrepreneurs, who essentially sift through the general body of knowledge until they find something they believe they can exploit and then start a business based on that piece of knowledge. Thus, knowledge by itself is not enough to create economic growth, since entrepreneurship is required to turn general knowledge into economic knowledge (Smith, 2010).

\section{Entrepreneurship in Greece}

The status and attitudes towards entrepreneurship in Greece can be examined from the data gathered by the Global Entrepreneurship Monitor (GEM). The Global Entrepreneurship Monitor project is an annual assessment of entrepreneurial activity, aspirations and attitudes across 85 countries. The data collected by GEM is 'harmonized', so as to facilitate cross-national comparisons. In order to make comparisons with other European countries, the Greek data will be presented along with the data for six other European countries: Sweden, Portugal, Spain, France, the United Kingdom and Germany. Five main indicators will be analysed: 
1) Established Business Ownership Rate

2) Total early-stage Entrepreneurial Activity

3) Necessity-Driven Entrepreneurial Activity

4) Entrepreneurial Intention

5) Fear of Failure Rate

\subsection{Established Business Ownership Rate}

According to GEM, Established Business Ownership Rate refers to the percentage of 18-64 population who are currently owner or manager of an established business, i.e. owning and managing a running business that has paid salaries, wages, or any other payments to the owners for more than 42 months. The rates for the seven countries are presented in Table 1.

Table 1: Established Business Ownership Rate

\begin{tabular}{llllllllllll}
\hline & 2001 & 2002 & 2003 & 2004 & 2005 & 2006 & 2007 & 2008 & 2009 & 2010 & 2011 \\
\hline Greece & - & - & 19.6 & 6.5 & 10.5 & 8.2 & 13.3 & 12.6 & 15.1 & 14.8 & 15.8 \\
Sweden & 5.7 & 6.8 & 5.3 & 6 & 6.3 & 5 & 4.7 & 5.2 & 5.8 & 6.4 & 7 \\
Portugal & 4.7 & 5.6 & 6.5 & 7.3 & 7.2 & 7.1 & 7.1 & 6.5 & 6 & 5.4 & 5.7 \\
Spain & 4.7 & 8.4 & 4 & 7.8 & 7.7 & 5.4 & 6.4 & 9.1 & 6.4 & 7.7 & 8.9 \\
UK & 3.3 & 5.5 & 5.8 & 5.1 & 5.1 & 5.4 & 5.1 & 6 & 6.1 & 6.4 & 7.2 \\
France & 1.6 & 1.3 & 1.6 & 1.5 & 2.3 & 1.3 & 1.7 & 2.8 & 3.2 & 2.4 & 2.4 \\
Germany & 4.2 & 4.8 & 4.6 & 4.3 & 4.2 & 3 & 3.5 & 4 & 5.1 & 5.7 & 5.6 \\
\hline
\end{tabular}

Source: Global Entrepreneurship Monitor, 2012

By looking at Table 1, we can see that Greece clearly has the highest rate of established business owners from the seven countries compared (available data for Greece start on 2003).

The percentage of business owners has increased from about 6.5\% of the population on 2004, to almost $15.8 \%$ on 2011.

Figure 1 presents the mean value for the seven countries, for the 11 year period (2001-2011). 


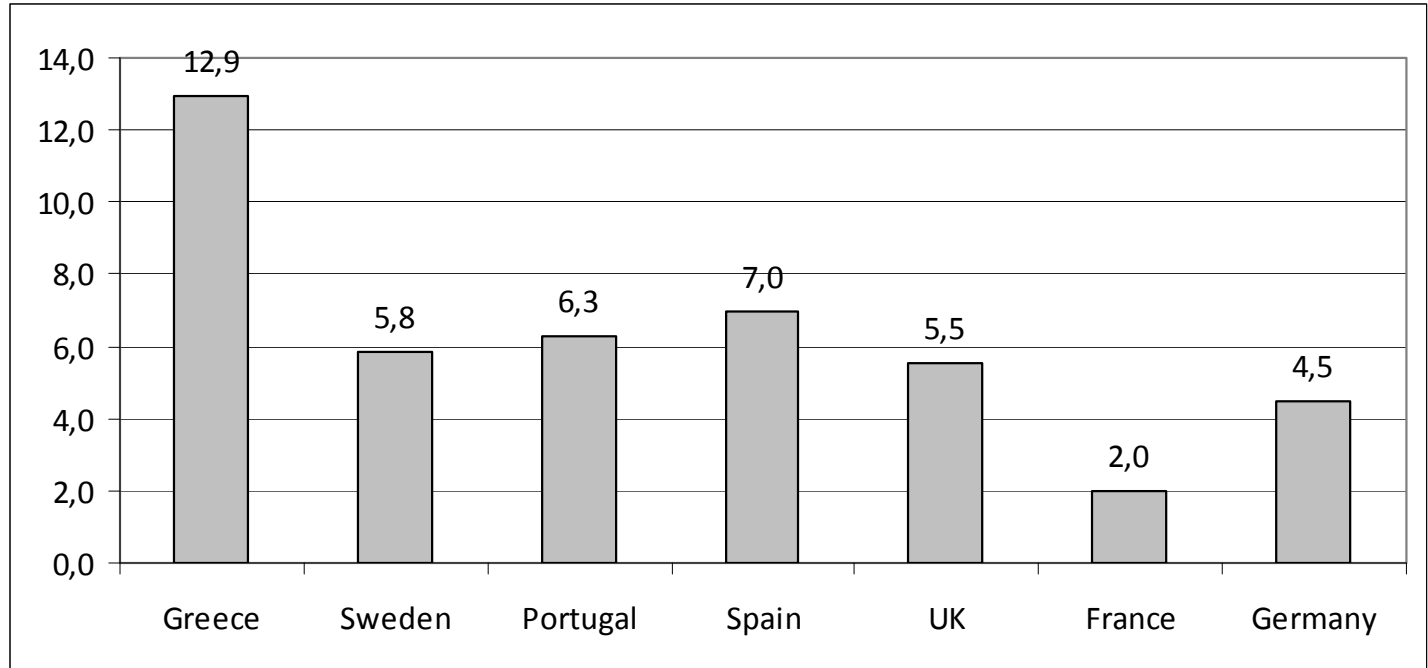

Figure 1: Established Business Ownership 11 year period mean \%

Source: Global Entrepreneurship Monitor, 2012

Greece has the highest mean value of established business ownership for the 11 year period (12.9\%), followed by Spain (7\%). The country with the lowest mean value is France (2\%).

\subsection{Total Early-Stage Entrepreneurial Activity}

GEM defines Total Early-Stage Entrepreneurial as the percentage of 18-64 population, who are either a nascent entrepreneur or owner-manager of a new business. The results are presented in Table 2.

Table 2: Total Early-Stage Entrepreneurial Activity

\begin{tabular}{llllllllllll}
\hline & 2001 & 2002 & 2003 & 2004 & 2005 & 2006 & 2007 & 2008 & 2009 & 2010 & 2011 \\
\hline Greece & - & - & 6.8 & 5.8 & 6.5 & 7.9 & 5.7 & 9.9 & 8.8 & 5.5 & 8 \\
Sweden & 3.8 & 3.9 & 4.1 & 3.7 & 4 & 3.4 & 4.2 & 4.4 & 4.6 & 4.9 & 5.8 \\
Portugal & 5.2 & 4.9 & 4.2 & 3.8 & 5.6 & 7 & 8.8 & 7.2 & 5.9 & 4.4 & 7.5 \\
Spain & 5.4 & 4.6 & 6.6 & 5.1 & 5.7 & 7.3 & 7.6 & 7 & 5.1 & 4.3 & 5.8 \\
UK & 5.4 & 5.4 & 6.4 & 6.2 & 6.2 & 5.8 & 5.5 & 5.9 & 5.7 & 6.4 & 7.3 \\
France & 2.6 & 3.1 & 1.6 & 6 & 5.4 & 4.4 & 3.2 & 5.6 & 4.3 & 5.8 & 5.7 \\
Germany & 5.8 & 5.2 & 5.2 & 4.4 & 5.1 & 4.2 & 4 & 3.8 & 4.1 & 4.2 & 5.6 \\
\hline
\end{tabular}

Source: Global Entrepreneurship Monitor, 2012

Figure 2 indicates that total early-stage entrepreneurial activity in Greece ranges from 6.8\% on 2003 , to almost $10 \%$ on 2008 and back to $8 \%$ in 2010. A decline in the percentage in early stage entrepreneurial activity can be observed after 2008 (after the economic crisis broke out).

Figure 2 presents the mean value for the seven countries, for the 11 year period (2001-2011). 


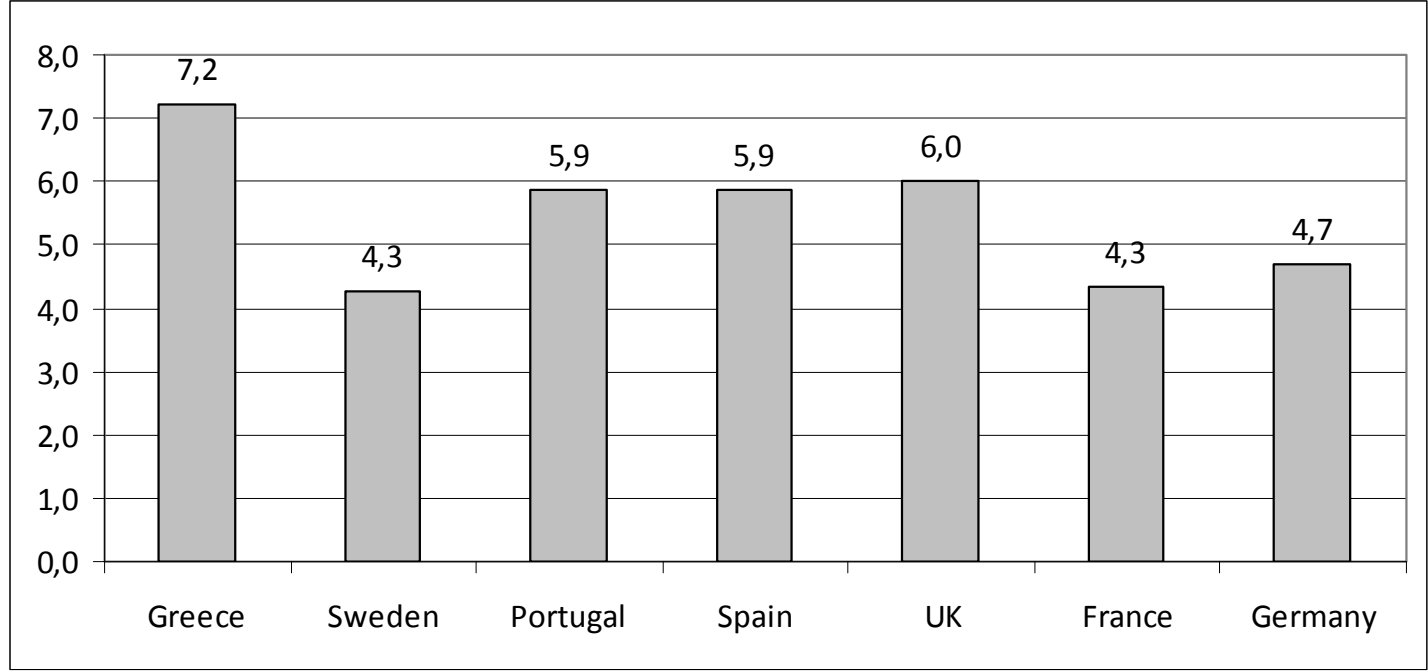

Figure 2: Total early-stage Entrepreneurial Activity 11 year period mean \%

Source: Global Entrepreneurship Monitor, 2012

Greece has the highest mean value of total early stage entrepreneurial activity (7.2\%), followed by the UK (6\%). Sweden and France have the lowest ones (4.3\%).

\subsection{Necessity-Driven Entrepreneurial Activity}

As defined from GEM, Necessity-Driven Entrepreneurial Activity refers to the percentage of people who are involved in entrepreneurship, because they had no other option for work. The results are presented in Table 3.

Table 3: Necessity-Driven Entrepreneurial Activity

\begin{tabular}{llllllllllll}
\hline & 2001 & 2002 & 2003 & 2004 & 2005 & 2006 & 2007 & 2008 & 2009 & 2010 & 2011 \\
\hline Greece & - & - & 38 & 29 & 14 & 21 & 10 & 31 & 26 & 28 & 25 \\
Sweden & 11 & 17 & 9 & 9 & 14 & 7 & 10 & 11 & 12 & 13 & 6 \\
Portugal & 19 & 21 & 23 & 26 & 21 & 15 & 10 & 14 & 18 & 22 & 18 \\
Spain & 22 & 22 & 5 & 12 & 14 & 15 & 15 & 15 & 16 & 25 & 26 \\
UK & 14 & 13 & 15 & 10 & 11 & 15 & 11 & 14 & 17 & 11 & 17 \\
France & 17 & 3 & 22 & 23 & 39 & 39 & 24 & 10 & 14 & 25 & 15 \\
Germany & 17 & 22 & 23 & 28 & 31 & 36 & 32 & 26 & 31 & 26 & 19 \\
\hline
\end{tabular}

Source: Global Entrepreneurship Monitor, 2012

Table 3 indicates that in Greece, from 2007 onwards, there has been a large increase in the necessity-driven entrepreneurial activity, from $10 \%$ on 2007 to $25 \%$ on 2011 . The highest overall necessity-driven entrepreneurial activity can be observed in Germany, ranging from $17 \%$ to $36 \%$ during the last decade.

Figure 3 presents the mean value for the seven countries, for the 11 year period (2001-2011). 


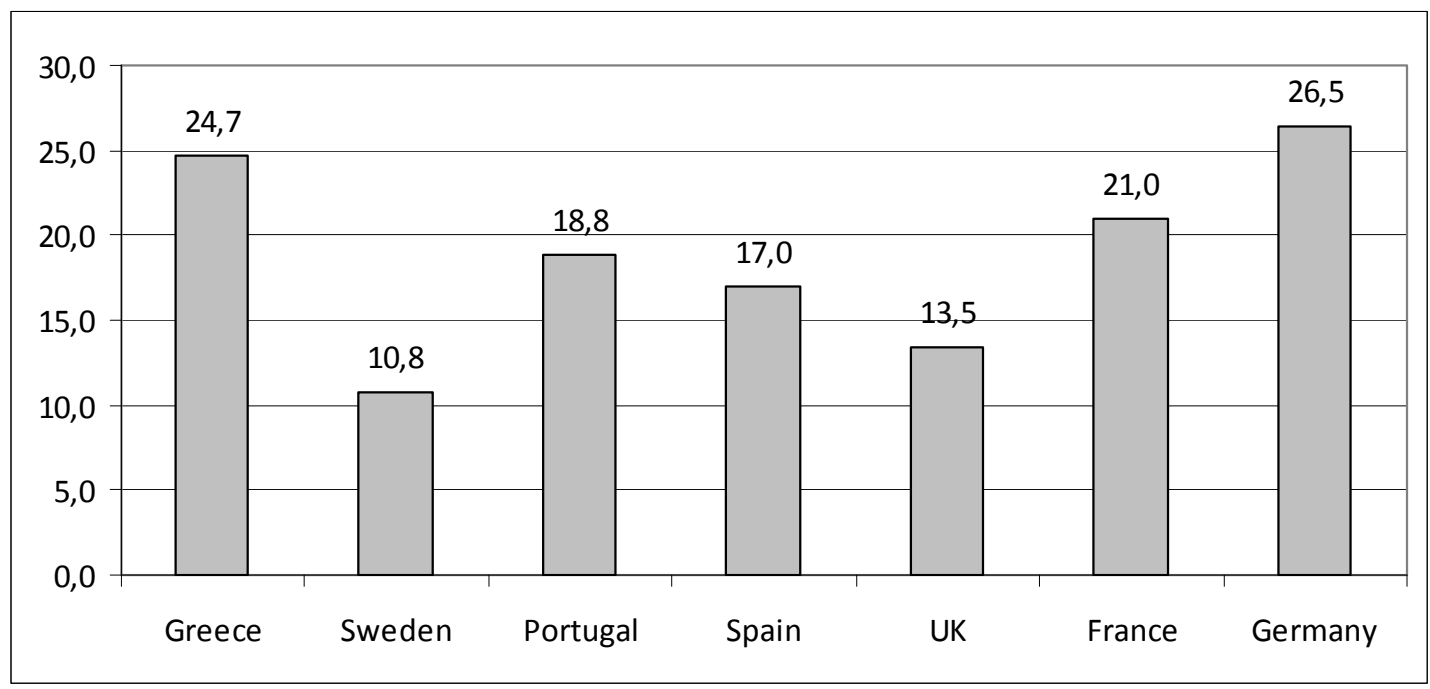

Figure 3: Necessity-Driven Entrepreneurial Activity 11 year period mean \%

Source: Global Entrepreneurship Monitor, 2012

As seen in Figure 3, the highest mean value of necessity driven entrepreneurial activity for the 11 year period can be observed in Germany (26.5\%), followed by Greece (24.7\%). The lowest value can be observed in Sweden (10.8\%).

\subsection{Entrepreneurial Intention}

GEM defines Entrepreneurial Intention as the percentage of 18-64 population (individuals involved in any stage of entrepreneurial activity excluded), who intend to start a business within three years. Table 4 presents the results.

Table 4: Entrepreneurial Intention

\begin{tabular}{llllllllllll}
\hline & 2001 & 2002 & 2003 & 2004 & 2005 & 2006 & 2007 & 2008 & 2009 & 2010 & 2011 \\
\hline Greece & - & - & 11.4 & 11.4 & 14.7 & 12.5 & 11.8 & 12.6 & 14.6 & 12.8 & 10.5 \\
Sweden & 12.5 & 12.7 & 10 & 14.3 & 9.3 & 9 & 8.9 & 8.8 & 8.7 & 8.5 & 9.8 \\
Portugal & - & - & & 2.2 & 4.8 & 7.2 & 9.8 & 9.5 & 9.2 & 8.8 & 12.2 \\
Spain & - & 7 & 4.9 & 4.3 & 4.2 & 4.4 & 4.3 & 5 & 4.3 & 5.8 & 8 \\
UK & - & 4.2 & 5.4 & 7.4 & 6.7 & 5.6 & 5.6 & 5.3 & 4.3 & 5.1 & 8.9 \\
France & - & 3 & 5.8 & 11.6 & 11.4 & 13.3 & 15.3 & 12.7 & 15.9 & 14.2 & 17.7 \\
Germany & - & 4.5 & 5.6 & 4.2 & 5.3 & 5.3 & 4.7 & 4.2 & 5.3 & 6.4 & 5.5 \\
\hline
\end{tabular}

Source: Global Entrepreneurship Monitor, 2012

As seen in Table 4, the highest rates of entrepreneurial intention can be observed in France (17.7\% in 2010) and Greece (12.8\% in 2010). Sweden presents a decline in entrepreneurship intention (from 14.3\% in 2005 to 9.8\% in 2010), while Portugal presents a large increase (from $2.2 \%$ in 2004 to $12.2 \%$ in 2011).

Figure 4 presents the mean value for the seven countries, for the 11 year period (2001-2011). 


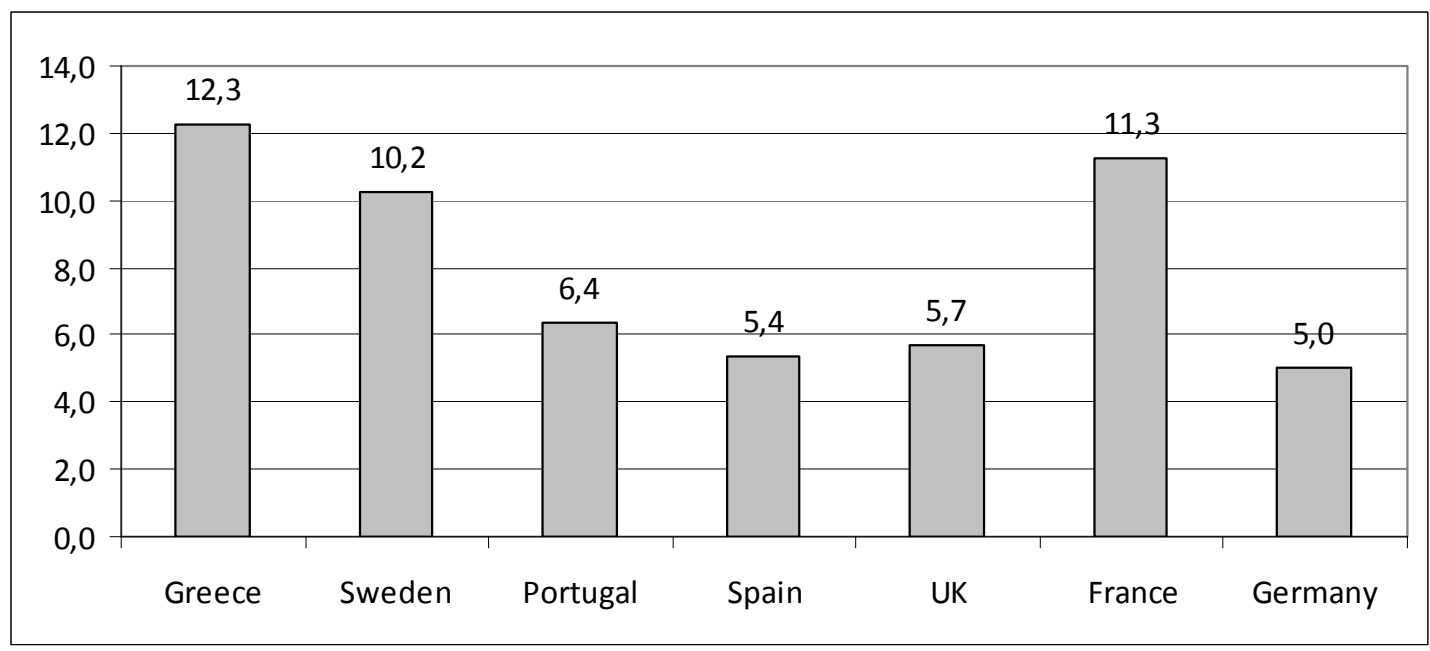

Figure 4: Entrepreneurial Intention 11 year period mean \%

Source: Global Entrepreneurship Monitor, 2012

From Figure 4 we can observe that Greece has the largest mean value of entrepreneurial intention from the 7 countries examined (12.3\%). The lowest value is observed in Germany (5\%).

\subsection{Fear of Failure Rate}

Finally, GEM refers to Fear of Failure Rate as the percentage of 18-64 population with positive perceived opportunities about entrepreneurship, who indicate that fear of failure would prevent them from setting up a business. The rate is presented in Table 5.

Table 5: Fear of Failure Rate

\begin{tabular}{llllllllllll}
\hline & 2001 & 2002 & 2003 & 2004 & 2005 & 2006 & 2007 & 2008 & 2009 & 2010 & 2011 \\
\hline Greece & - & - & 49 & 48 & 50 & 48 & 54 & 46 & 45 & 51 & 38 \\
Sweden & 31 & 30 & 30 & 32 & 34 & 28 & 29 & 29 & 29 & 29 & 35 \\
Portugal & 31 & 30 & 29 & 29 & 29 & 29 & 29 & 29 & 30 & 30 & 40 \\
Spain & 36 & 42 & 40 & 45 & 42 & 44 & 47 & 47 & 45 & 36 & 39 \\
UK & 33 & 33 & 31 & 33 & 33 & 33 & 34 & 34 & 32 & 30 & 36 \\
France & 29 & 22 & 34 & 42 & 42 & 43 & 41 & 52 & 47 & 40 & 37 \\
Germany & 42 & 37 & 33 & 30 & 40 & 34 & 36 & 40 & 37 & 34 & 42 \\
\hline
\end{tabular}

Source: Global Entrepreneurship Monitor, 2012

As seen from the table, the fear of failure rate is quite high in all the sample countries, ranging from $22 \%$ to $54 \%$. The highest fear of failure percentage is observed in Greece (54\% in 2007), while the lowest value is observed in France (22\% in 2002).

Figure 5 presents the mean value for the seven countries, for the 11 year period (2001-2011). 


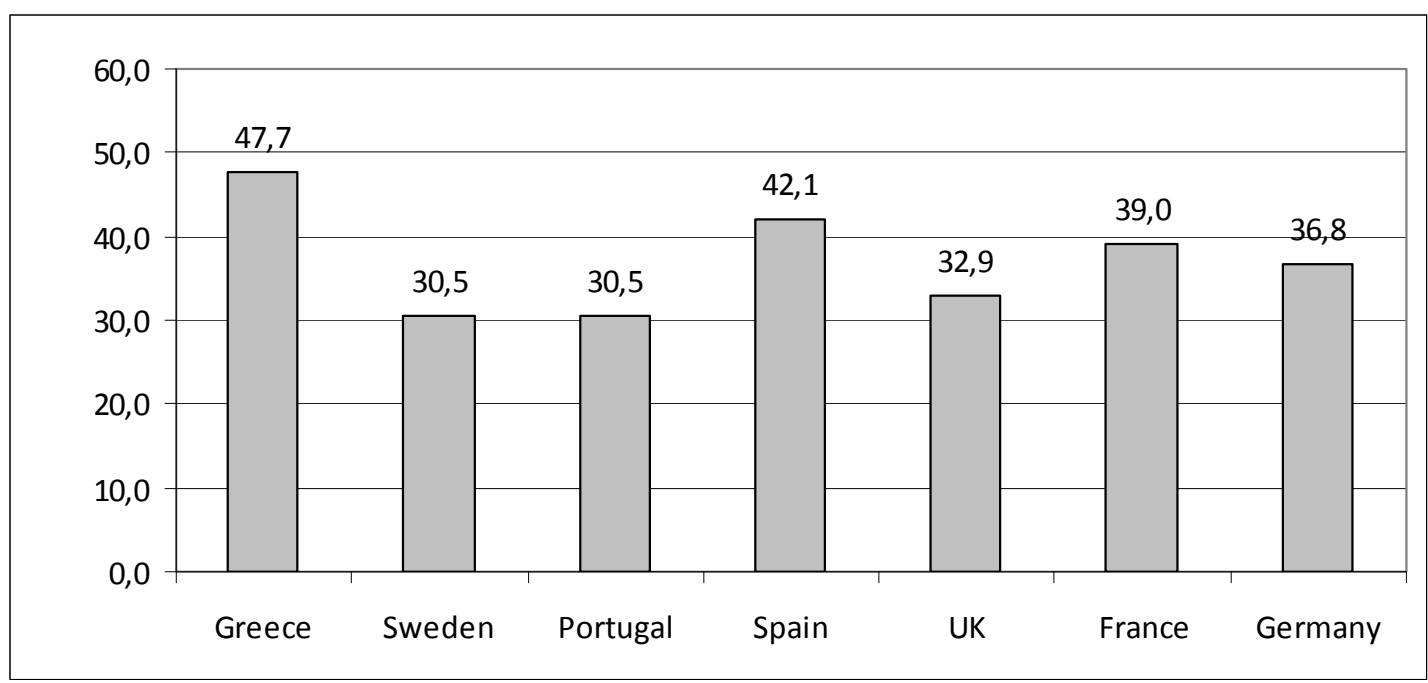

Figure 5: Fear of Failure Rate 11 year period mean \%

Source: Global Entrepreneurship Monitor, 2012

In Figure 5 we observe that the highest mean value of fear of failure for the 11 year period, was recorded in Greece (47.7\%), while the lowest one in Sweden and Portugal (30.5\%).

\section{Business Statistics}

In order to have a better picture of the Greek business sector, following there is going to be a presentation of Greek business demographic data. Data for the six other European countries previously used will be presented as well. These data come from the OECD, but they concern the year 2007. Despite the six year period since then, these statistics can still offer a good insight in the Greek business sector.

The data presented concern the following aspects:

1) Enterprises by size class

2) Value Added by size class

3) Employment by size class

The OECD uses 5 size classes, all measured according to the number of employees:

a) 1-9 (micro enterprises)

b) 10-19 (small enterprises)

c) 20-49 (small enterprises)

d) 50-249 (medium enterprises)

e) 250+ (large enterprises)

The first 4 categories are called Small Medium Enterprises (SMEs). 


\subsection{Enterprises by Size Class}

Table 6 presents the total number of businesses by size class for the seven European countries. Size is measured from the number of employees they occupy. In the last column we see the total amount of businesses counted in every economy.

Table 6: Enterprises by Size Class 2007 (values)

\begin{tabular}{llllllr}
\hline & \multicolumn{1}{c}{$1-9$} & $10-19$ & $20-49$ & $50-249$ & \multicolumn{1}{c}{$250+$} & Total \\
\hline Germany & 1510416 & 174615 & 81156 & 43727 & 8995 & 1818909 \\
UK & 1468612 & 116995 & 51449 & 27433 & 6.083 & 1670572 \\
Spain & 2511563 & 112425 & 63096 & 22008 & 3305 & 2712397 \\
France & 2388341 & 96070 & 56334 & 23184 & 5125 & 2569054 \\
Sweden & 527618 & 17117 & 10223 & 4861 & 1012 & 560831 \\
Portugal & 819713 & 26706 & 13988 & 5788 & 839 & 867034 \\
Greece & 801251 & 16474 & 7912 & 2905 & 470 & 829012 \\
\hline
\end{tabular}

Source: OECD, 2011

The largest number of businesses is met in Spain (2.7 million), followed by France (2.5 million), Germany (1.8 million), the UK (1.6 million), Portugal (867 thousands), Greece (829 thousands) and finally Sweden (560 thousands). In order to examine size classes in more detail, it is useful to look at percentages, as presented in Table 7 and Figure 6.

Table 7: Enterprises by Size Class 2007 (\%)

\begin{tabular}{llllll}
\hline & $1-9$ & $10-19$ & $20-49$ & $50-249$ & $250+$ \\
\hline Germany & 83.0 & 9.6 & 4.5 & 2.4 & 0.5 \\
UK & 87.9 & 7.0 & 3.1 & 1.6 & 0.4 \\
Spain & 92.6 & 4.1 & 2.3 & 0.8 & 0.1 \\
France & 93.0 & 3.7 & 2.2 & 0.9 & 0.2 \\
Sweden & 94.1 & 3.1 & 1.8 & 0.9 & 0.2 \\
Portugal & 94.5 & 3.1 & 1.6 & 0.7 & 0.1 \\
Greece & 96.7 & 2.0 & 1.0 & 0.4 & 0.1 \\
\hline
\end{tabular}

Source: OECD, 2011 


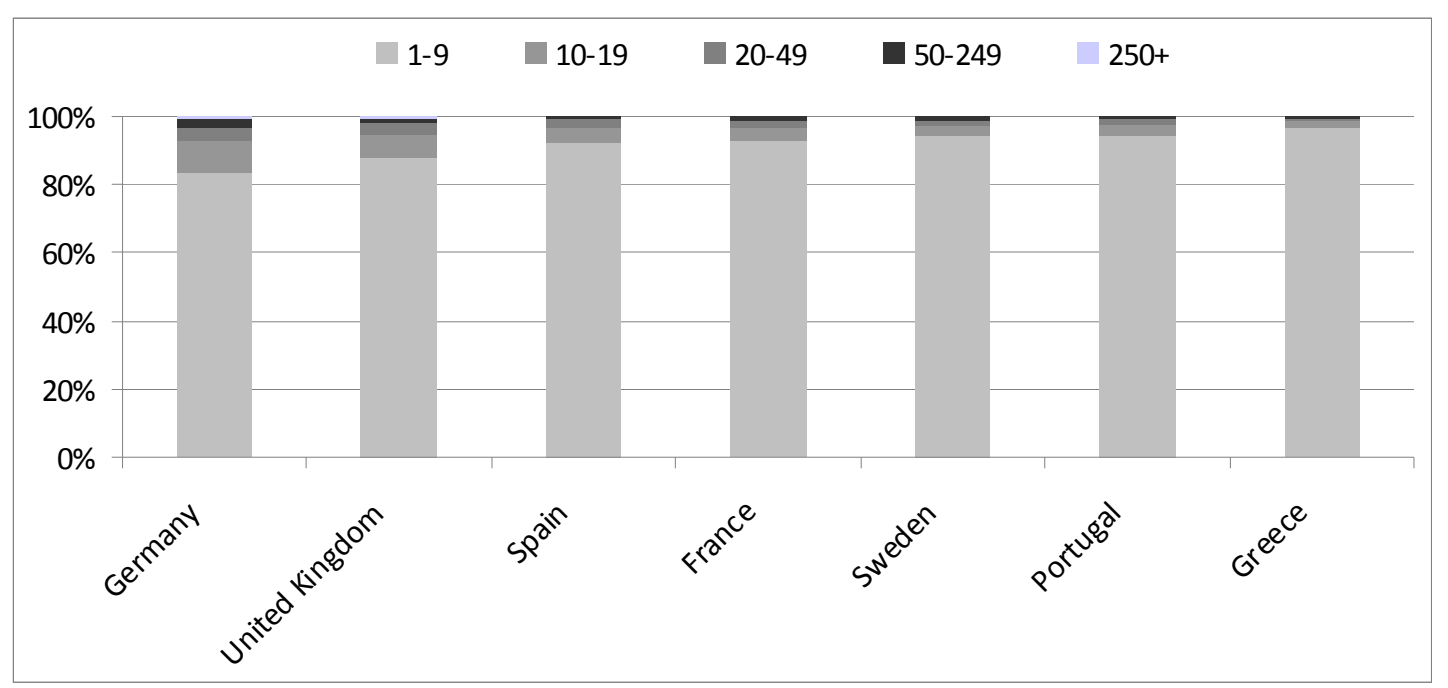

Figure 6: Enterprises by Size Class 2007 (\%)

Source: OECD, 2011

Looking at the business size percentages, it is evident that most businesses in the seven European countries examined, are micro enterprises, meaning that they have less than 10 employees. The percentage of micro enterprises ranges from $83 \%$ in Germany, to $96.7 \%$ in Greece. Small enterprises in Greece (those with 10-49 employees) are around 3\% (24.386 enterprises), medium are $0.4 \%$ (2.905 enterprises) and large only $0.1 \%$ (470 enterprises)

\subsection{Value added by Size Class}

According to the OECD, value added corresponds to the difference between production and any intermediate consumption, where total intermediate consumption is valued at purchasers' prices. Table 8 presents value added by size class for the seven European economies.

Table 8: Value Added by Size Class 2007 (millions €)

\begin{tabular}{lllllll}
\hline & $1-9$ & $10-19$ & \multicolumn{1}{c}{$20-49$} & $50-249$ & $250+$ & \multicolumn{1}{c}{ Total } \\
\hline Germany & 189120 & 93368 & 113219 & 233934 & 543551 & 1173192 \\
UK & 144639 & 56334 & 67206 & 132895 & 385246 & 786320 \\
Sweden & 336468 & 124480 & 177560 & 300172 & 722481 & 1661161 \\
France & 184800 & 64212 & 94165 & 127708 & 370095 & 840980 \\
Portugal & 17464 & 7241 & 9968 & 15930 & 21670 & 72273 \\
Spain & 158498 & 53184 & 77666 & 102082 & 183888 & 575318 \\
Greece & 26903 & 6641 & 9122 & 11484 & 17999 & 72149 \\
\hline
\end{tabular}

Source: OECD, 2011

The highest total value added is recorded in Sweden (1.6 trillion €), followed by Germany (1.1 trillion $€$ ), France (840 billion $€$ ), the UK (786 billion $€$ ), Spain (575 billion $€$ ), Portugal (72 billion $€$ ) and finally Greece (72 billion $€$ ). In order to examine the contribution of each size class in more detail, it is useful to look at percentages, as presented in Table 9 and Figure 7. 
Table 9: Value Added by Size Class 2007 (\%)

\begin{tabular}{lcllll}
\hline & $1-9$ & $10-19$ & $20-49$ & $50-249$ & $250+$ \\
\hline Germany & 16.1 & 8.0 & 9.7 & 19.9 & 46.3 \\
UK & 18.4 & 7.2 & 8.5 & 16.9 & 49.0 \\
Sweden & 20.3 & 7.5 & 10.7 & 18.1 & 43.5 \\
France & 22.0 & 7.6 & 11.2 & 15.2 & 44.0 \\
Portugal & 24.2 & 10.0 & 13.8 & 22.0 & 30.0 \\
Spain & 27.5 & 9.2 & 13.5 & 17.7 & 32.0 \\
Greece & 37.3 & 9.2 & 12.6 & 15.9 & 24.9 \\
\hline
\end{tabular}

Source: OECD, 2011

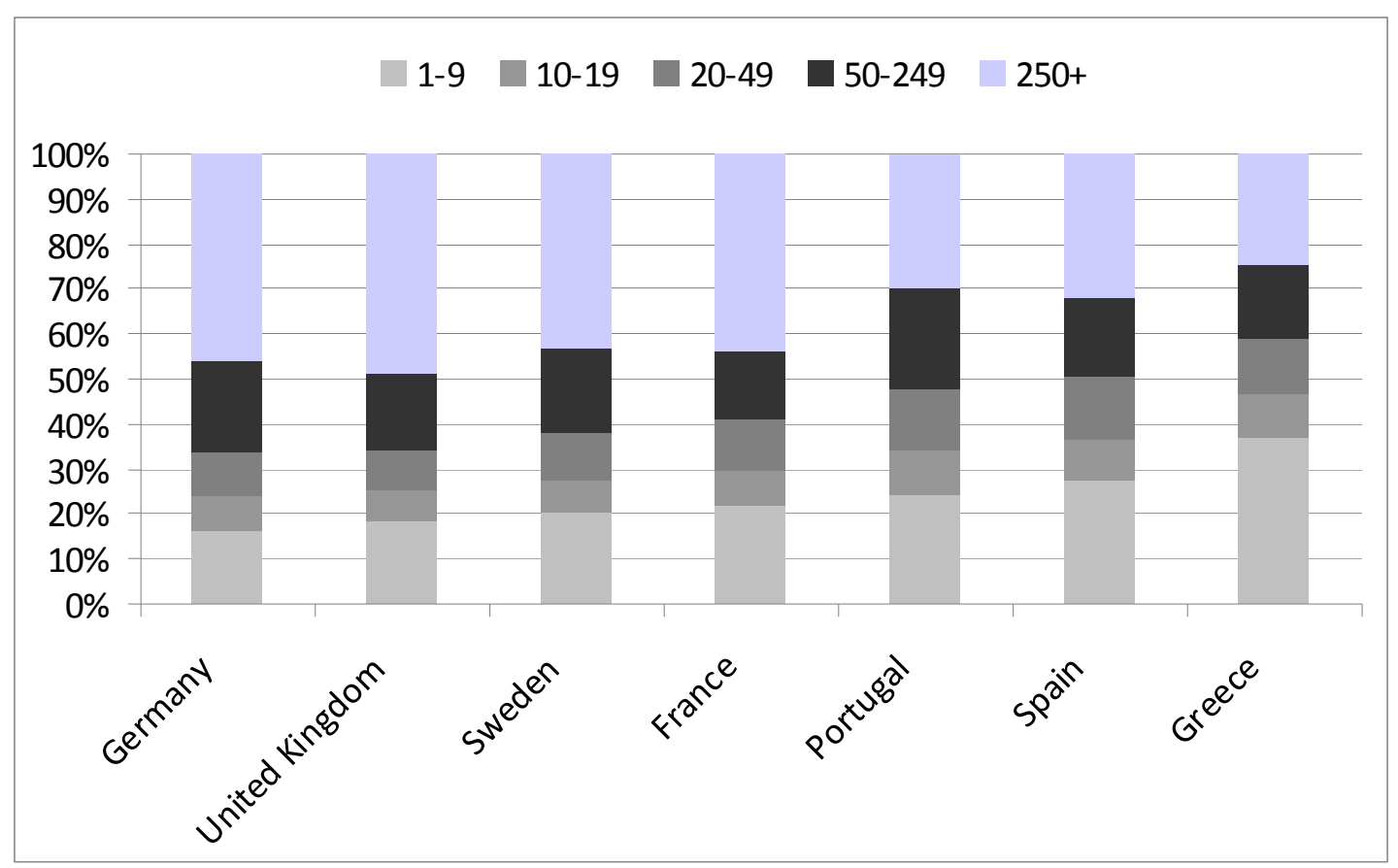

Figure 7: Value Added by Size Class 2007 (\%)

Source: OECD, 2011

Micro enterprises in Greece offer 37.3\% of total value added, while SMEs offer $75 \%$. This percentage is the largest contribution of SMEs in the economy for the 7 counties. Large enterprises, even though they are only $0.1 \%$ of total enterprises, they offer $24.9 \%$ of the private sector's total value added. However this percentage is by far the lowest one from the 7 countries examined. The largest contribution of large enterprises is observed in the UK (49\%). followed by Germany (46.3\%) and Sweden (43.5\%).

\subsection{Employment by Size Class}

Table 10 presents data concerning the number of employees that work in each size class, for the seven European countries. The last column presents the total private sector workforce. 
Table 10: Employment by Size Class 2007 (values)

\begin{tabular}{lllrrrl}
\hline & \multicolumn{1}{c}{$1-9$} & $10-19$ & $20-49$ & $50-249$ & \multicolumn{1}{c}{$250+$} & \multicolumn{1}{c}{ Total } \\
\hline Germany & 424452 & 2342985 & 2457605 & 4354889 & 8800230 & 22199161 \\
UK & 3898329 & 1562194 & 1590442 & 2756434 & 8329493 & 18136892 \\
France & 3673665 & 1301770 & 1772748 & 2389409 & 5966660 & 15104252 \\
Sweden & 702526 & 261584 & 342046 & 524751 & 1042929 & 2873836 \\
Spain & 5456091 & 1540760 & 1955014 & 2115745 & 3193120 & 14260730 \\
Portugal & 1389008 & 350016 & 413361 & 545157 & 627185 & 3324727 \\
Greece & 1513452 & 213860 & 241815 & 276970 & 353931 & 2600028 \\
\hline
\end{tabular}

Source: OECD, 2011

The largest number of employees was recorded in Germany (22.1 million), followed by the UK (18.1 million), France (15.1 million), Spain (14.2 million), Portugal (3.3 million), Sweden (2.8 million) and finally Greece (2.6 million).(Note 1) In order to examine employment of each size class in more detail, it is useful to look at percentages, as presented in Table 11 and Figure 8.

Table 11: Employment by Size Class 2007 (\%)

\begin{tabular}{llllll}
\hline & $1-9$ & $10-19$ & $20-49$ & $50-249$ & $250+$ \\
\hline Germany & 19.1 & 10.6 & 11.1 & 19.6 & 39.6 \\
UK & 21.5 & 8.6 & 8.8 & 15.2 & 45.9 \\
France & 24.3 & 8.6 & 11.7 & 15.8 & 39.5 \\
Sweden & 24.4 & 9.1 & 11.9 & 18.3 & 36.3 \\
Spain & 38.3 & 10.8 & 13.7 & 14.8 & 22.4 \\
Portugal & 41.8 & 10.5 & 12.4 & 16.4 & 18.9 \\
Greece & 58.2 & 8.2 & 9.3 & 10.7 & 13.6 \\
\hline
\end{tabular}

Source: OECD, 2011 


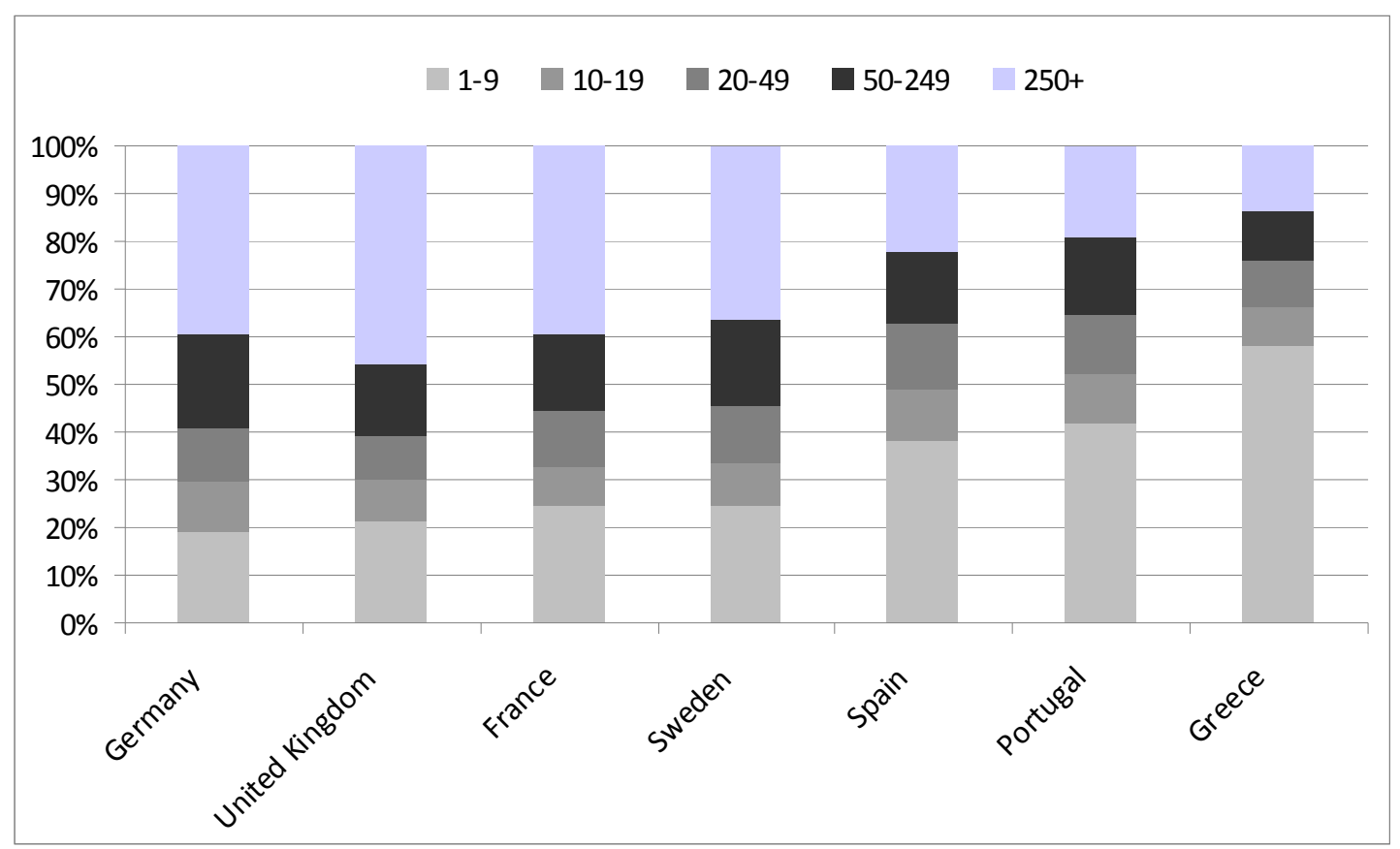

Figure 8: Employment by Size Class 2007 (percentages)

Source: OECD, 2011

Micro enterprises in Greece are responsible for the $58.2 \%$ of total private sector employment. This percentage is much higher than all other countries and highlights the importance of micro enterprises in the economy. Large enterprises in Greece occupy 13.6\% of private sector workforce, which is the lowest percentage of the seven countries. The largest percentage of large enterprises employment is met in the UK (45.9\%), followed by Germany (39.6\%), France (39.5\%), Sweden (36.3\%), Spain (22.4\%) and Portugal (18.9\%).

\section{Business Failure}

Having examined Greek entrepreneurship data and structural business statistics, it is useful to see the country's business prospects.

Greece, due to a combination of microeconomic and macroeconomic long term weaknesses, in 2009 was faced with a large deficit problem (15.3\% of GDP). This fiscal deficit increased drastically the borrowing interest rates, and as a solution the country turned to the International Monetary Fund (IMF) for assistance. The IMF agreed to lend funds to the Greek government, by signing two cooperation memorandums. These memorandums included various lending terms, as cutting government spending, increasing taxes and lowering wage rates. Even though some of the lending terms were useful for the economy, others have proven completely inefficient and suffocating for the market. The country is in its fourth year of recession and as a result many businesses, especially SMEs, are closing. 
Table 12 presents the numbers of Greek enterprises according to Eurostat.

Table 12: Number of Enterprises by Size Class in Greece

\begin{tabular}{llllllll}
\hline & 2005 & \multicolumn{1}{c}{2006} & \multicolumn{1}{c}{2007} & \multicolumn{1}{c}{2008} & \multicolumn{1}{c}{2009} & \multicolumn{1}{c}{2010} & 2011 \\
\hline $0-9$ & 796520 & 799854 & 801723 & 782763 & 756244 & 719952 & 695733 \\
$10-49$ & 21246 & 25250 & 24604 & 24406 & 23780 & 22832 & 22075 \\
$50-249$ & 2519 & 3496 & 2947 & 2982 & 2965 & 2893 & 2894 \\
SMEs & 820285 & 828600 & 829274 & 810151 & 782989 & 745677 & 720702 \\
$250+$ & 468 & 429 & 478 & 515 & 556 & 563 & 577 \\
Total & 820753 & 829029 & 829752 & 810666 & 783545 & 746240 & 721277 \\
\hline
\end{tabular}

Source: Eurostat, $2012 *(2009,2010,2011$ Eurostat estimates)

The total number of enterprises in 2005 was over 820753, out of which 820285 were SMEs. In 2011 the total number of enterprises was 721277, out of which 720702 were SMEs. The number of large enterprises has increased from 468 in 2005, to 577 on 2011. By subtracting from each year the value of the previous year, we can calculate the increase or decrease in the number of firms. These are estimated as follows:

Table 13: Business Closures in Greece

\begin{tabular}{lllllll}
\hline & 2006 & \multicolumn{1}{c}{2007} & \multicolumn{1}{c}{2008} & \multicolumn{1}{c}{2009} & \multicolumn{1}{c}{2010} & \multicolumn{1}{c}{2011} \\
\hline $0-9$ & 3334 & 1869 & -18960 & -26519 & -36292 & -24219 \\
$10-49$ & 4004 & -646 & -198 & -626 & -948 & -757 \\
$50-249$ & 977 & -549 & 35 & -17 & -72 & 1 \\
SMEs & 8315 & 674 & -19123 & -27162 & -37312 & -24975 \\
$250+$ & -39 & 49 & 37 & 41 & 7 & 14 \\
Total & 8276 & 723 & -19086 & -27121 & -37305 & -24963 \\
\hline
\end{tabular}

Source: Eurostat, $2012 *(2009,2010,2011$ Eurostat estimates)

During 2006 and 2007 there was an increase in the number of firms in the economy. From 2009 up to 2011, there has been a large decrease in the total number of enterprises, mainly due to massive closure of micro firms. According to Eurostat estimates, the total number of SMEs that closed between 2008, 2009, 2010 and 2011 is 108572. However, the number of large firms has increased from 2007 onwards.

Business closures have also affected employment. The data presented on Table 14 originate from Eurostat and regard employment by size class in Greece for the period 2005-2011. 
Table 14: Employment by Size Class in Greece

\begin{tabular}{llllllll}
\hline & \multicolumn{1}{c}{2005} & \multicolumn{1}{c}{2006} & \multicolumn{1}{c}{2007} & \multicolumn{1}{c}{2008} & \multicolumn{1}{c}{2009} & \multicolumn{1}{c}{2010} & \multicolumn{1}{c}{2011} \\
\hline $0-9$ & 1401535 & 1500792 & 1515228 & 1519819 & 1500075 & 1447218 & 1410339 \\
$10-49$ & 392811 & 446709 & 459983 & 462716 & 457256 & 438792 & 423499 \\
$50-249$ & 242704 & 304802 & 281041 & 281860 & 277996 & 264427 & 256885 \\
SMEs & 2037050 & 2252303 & 2256252 & 2264395 & 2235327 & 2150437 & 2090723 \\
$250+$ & 455304 & 337117 & 380594 & 383779 & 379192 & 362055 & 349399 \\
Total & 2492354 & 2589420 & 2636846 & 2648174 & 2614518 & 2512492 & 2440121 \\
\hline
\end{tabular}

Source: Eurostat, $2012 *(2009,2010,2011$ Eurostat estimates)

The total number of employees working in the private sector in 2005 was over 2.4 million, out of which 2 million worked in SMEs. In 2011 the total number of employees was 2.4 million, out of which again 2 million worked in SMEs. In large enterprises, even though as seen in Tables 13, their number has increased during the period 2005-2011, the number of employees occupied has decreased.

Again, by subtracting from each year the value of the previous year, we can calculate the increase or decrease in employment by size class. These are estimated as follows:

Table 15: Job Losses in Greece 2006-2011

\begin{tabular}{lllllrl}
\hline & 2006 & 2007 & 2008 & 2009 & 2010 & \multicolumn{1}{c}{2011} \\
\hline $0-9$ & 99257 & 14436 & 4591 & -19744 & -52857 & -36879 \\
$10-49$ & 53898 & 13274 & 2733 & -5460 & -18464 & -15293 \\
$50-249$ & 62098 & -23761 & 819 & -3864 & -13569 & -7542 \\
SMEs & 215253 & 3949 & 8143 & -29068 & -84890 & -59714 \\
$250+$ & -118187 & 43477 & 3185 & -4587 & -17137 & -12656 \\
Total & 97066 & 47426 & 11328 & -33656 & -102026 & -72371 \\
\hline
\end{tabular}

Source: Eurostat, 2012*(2009, 2010, 2011 Eurostat estimates)

From 2009 onwards we can notice that there have been continuous job losses in all business size classes. Total job losses between 2009 and 2011 amount to 208053 (33656+102026+72371). The job losses in SMEs between 2009 and 2011 were 173673 $(29068+84890+59714)$, while in large enterprises they were $34380(4587+17137+12656)$.

Moreover, according to the 2011 Yearly Report on Greek Trade, by the National Confederation of Greek Trade, the closures expected for 2012 range between 50000 and 60000 and the job losses around 100000. Regarding the job losses, the Employment Institute of the General Confederation of Greek Workers is more pessimistic. It expected around 500000 job losses in 2012.

\section{Business Barriers}

Many of the business closures mentioned above are a result of the barriers met by Greek 
enterprises. Barriers are met both during the start up phase as well during their daily operation. Following there is going to be a reference on various researches made on the topic.

In a research carried out by the World Bank on 2008, about the ease of starting a business, Greece was in the last position among 58 countries. On the same research for 2011, it was in the $101^{\text {th }}$ position from 183 countries. This research evaluated the ease of starting a business based on the following aspects: Starting a Business, Dealing with Construction Permits, Getting Electricity, Registering Property, Getting Credit, Protecting Investors, Paying Taxes, Trading Across Borders, Enforcing Contracts and Resolving Insolvency.

The OECD (2011) has carried out research on a relative topic, that of administrative burdens on start-ups. Administrative burdens on start ups measure a country's regulatory environment. They are calculated by using three main indicators: state control, barriers to entrepreneurship and barriers to trade and investment. Figure 9 pictures an analysis of the results for 20 European economies for the year 2008.

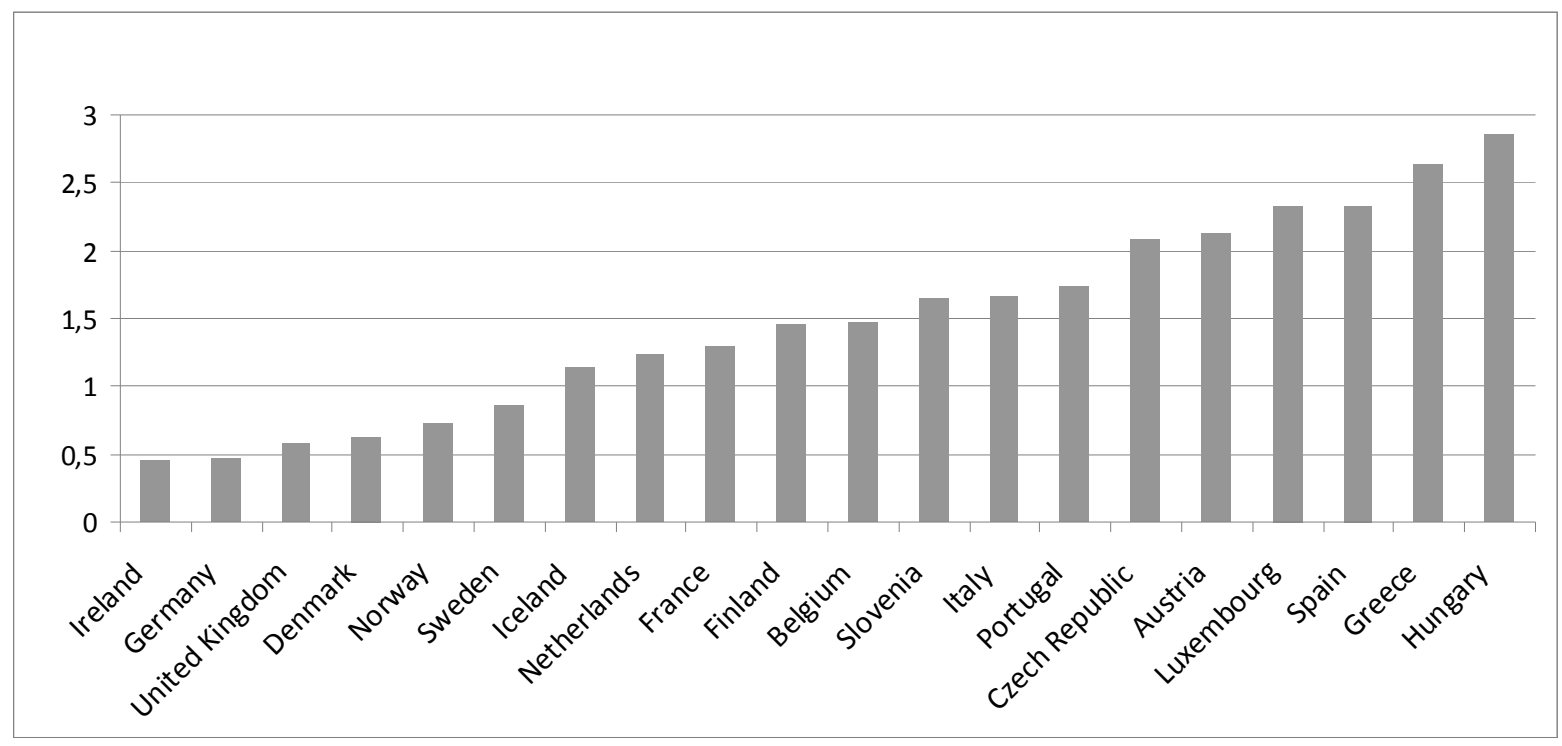

Figure 9: Administrative Burdens on Start-Ups (2008) (from 0 to 6 the more restricting)

Source: OECD, 2011 (*Data for Greece and Ireland refer to 2003)

Greece, along with Hungary, was evaluated to be the country with the most administrative burdens on start ups, scoring 2.6 and 2.8 respectively. The countries with the least administrative burdens to start ups were Ireland (0.4), Germany (0.49), the UK (0.55) and Denmark (0.6).

The OECD has also used Word Bank 2010 data, in order to measure the ease of starting a business (Figure 10). 


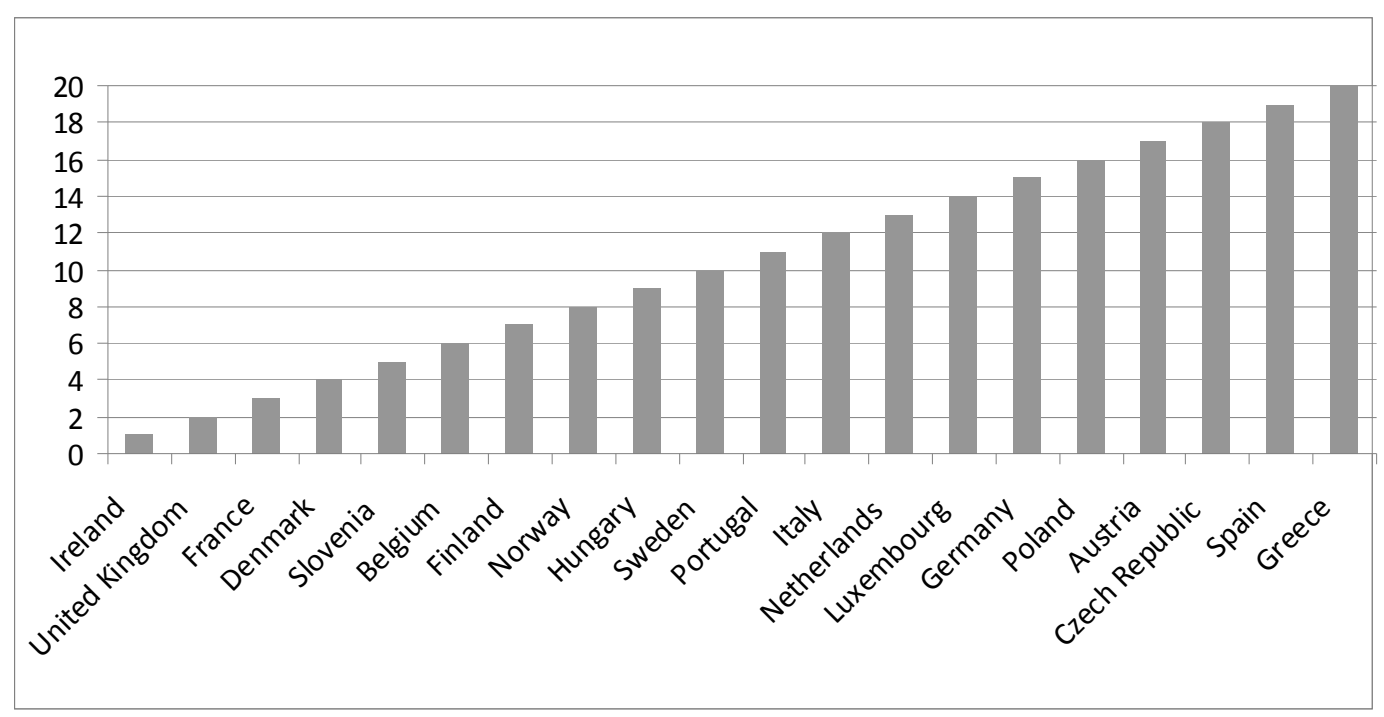

Figure 10: Starting a Business 2010 (Ranking of countries from least to more restricting)

Source: OECD, 2011

Using the World Bank data, Greece is the European country, among the other 20, where it is the most difficult to start a business. It is followed by Spain and the Czech Republic. The country where it is the easiest to start a business is Ireland, followed by the UK and France.

In order to examine which are the exact barriers met by firms that operate in the Greek economy, a reference will be made to a recent study on the topic. According to a study about business barriers made by the Centre for Studies and Research of the Athens Chamber of Industry and Commerce in a sample of 1.104 firms, between 3 and 24 October 2011, the results were the following (Tables 16 and 17):

Table 16: Very Important Barriers Met by Greek Enterprises

\begin{tabular}{lc}
\hline \multicolumn{1}{c}{ Barrier } & $\%$ of Respondents \\
\hline $\begin{array}{l}\text { Continuous changes and instability in the tax employment and insurance } \\
\text { status }\end{array}$ & $80 \%$ \\
Market psychology & $78 \%$ \\
Height of tax rates and other fees that make up the cost of running a business & $62 \%$ \\
Bureaucracy in dealing with the state & $57 \%$ \\
Inability to control black markets and shadow economy & $57 \%$ \\
Inability to fight tax evasion & $55 \%$ \\
Corruption in transactions between businesses and state & $52 \%$ \\
Reduction in purchasing power of workers and pensioners due to the & $51 \%$ \\
lowering of salaries and pensions & \\
Difficulty in accessing the banking system for financing & $49 \%$ \\
Height of social security contributions & $41 \%$ \\
Large public sector & $45 \%$ \\
Difficulty of accessing local national and European funding programs & $37 \%$ \\
\hline
\end{tabular}


Table 17: Moderately Important Barriers Met by Greek Enterprises

\begin{tabular}{ll}
\hline \multicolumn{1}{c}{ Barrier } & \% of Respondents \\
\hline Wage costs & $43 \%$ \\
Rent & $33 \%$ \\
Delayed privatization and opening of the professions & $26 \%$ \\
Demonstrations and marches & $25 \%$ \\
\hline
\end{tabular}

The results of this research are very enlightening. Business owners in Greece agree that the most important barriers they face are tax rates, employment and insurance status, market psychology and state bureaucracy. Three out four barriers originate directly from the government while the other one market psychology can be tackled by government action e.g. investments.

However, the policies that have been proposed by the IMF and have been applied in Greece so far, have increased tax rates, changed more than once the employment and insurance status, "froze" market psychology, due to public and private sector wage cuts and did almost nothing to lessen bureaucracy. It also striking that wage cost is not considered an important barrier by business owners. Many businesses have cut wages and fired personnel, in an attempt to minimise costs and escape closure, but this is due to the fact that businesses themselves cannot change any of the important barriers they face.

Another research on the same topic was carried out by the World Economic Forum in 2010. From a list of 15 factors, respondents were asked to select the five most problematic for doing business in their country, and to rank them between 1 (most problematic) and 5 . The results were as follows:

Table 18: Problematic Factors for Doing Business in Greece

\begin{tabular}{ll}
\hline \multicolumn{1}{c}{ Factors } & \% of Respondents \\
\hline Inefficient government bureaucracy & $27.2 \%$ \\
Corruption & $14 \%$ \\
Restrictive labor regulations & $12 \%$ \\
Policy instability & $11.5 \%$ \\
Tax regulations & $11.1 \%$ \\
Access to financing & $9.9 \%$ \\
Inadequate supply of infrastructure & $3.9 \%$ \\
Tax rates & $3.7 \%$ \\
Poor work ethic in national labor force & $2.3 \%$ \\
Government instability/coups & $2.3 \%$ \\
Inadequately educated workforce & $1.4 \%$ \\
Inflation & $0.6 \%$ \\
Crime and theft & $0.1 \%$ \\
Poor public health & $0.1 \%$ \\
Foreign currency regulations & $0 \%$ \\
\hline
\end{tabular}

From Table 18 again we notice that most barriers are related with the state. The most 
problematic factor is government bureaucracy (27.2\%), followed by corruption (14\%) restrictive labor regulations (12\%), policy instability (11.5\%) and tax regulations $(11.1 \%)$. Access to financing was also considered a problematic factor for businesses.

\section{Conclusions - Policy Recommendations}

Entrepreneurship plays a vital role in the Greek economy, as about $15 \%$ of the active populations are entrepreneurs. Most of the entrepreneurs have micro enterprises, which make up $96 \%$ of Greek businesses. These micro enterprises, offer 33\% of the total business sector value added and occupy 58\% of the business sector workforce SMEs in total offer $75 \%$ of total value added and occupy $77 \%$ of the total private sector workforce. However SMEs prospects at the moment are not good. During the last four years, at least 100000 businesses have gone out of business and about 200000 employees have lost their jobs. For 2012 another 50000 businesses are expected to close due to the recession, adding up more unemployed to the economy.

Large enterprises even though they are only $0.1 \%$ of total enterprises, they offer $24.9 \%$ of the private sector's total value added and occupy $13.6 \%$ of total private sector workforce. Even though the number of large enterprises has increased during the last years, the number of employees has decreased by 34380 .

As the role of the SMEs is vital for economic growth and innovation in every economy in the world, the Greek government must support them with every mean possible. The government should aim at abolishing the most important barriers met by Greek enterprises. According to the business owners, these are tax rates, employment and insurance status, market psychology and state bureaucracy.

The policies that have been proposed by the IMF and have been applied in Greece so far, have done exactly the opposite: they have increased tax rates, changed more than once the employment and insurance status, "froze" market psychology due to public and private sector wage cuts and did almost nothing to lessen bureaucracy. Notably, wage cost is not considered an important barrier by business owners. Many businesses have cut wages and fired personnel in an attempt to minimise costs and escape closure, but this is due to the fact that businesses themselves cannot change any of the important barriers they face.

As three out of four barriers originate directly from the government, while the other one, market psychology, can be tackled by government action, there is an urgent need for the Greek government to proceed to some decisive measures: lowering of taxes, minimization of the state bureaucracy and corruption, establishment of fair and effective employment and insurance laws and finally increases in wages, so as to increase buying power, are some of the basic policies that need to be followed in order to secure SMEs' short term survival and long term prosperity. The formation of more public private of mixed ownership large enterprises, would also be very helpful for boosting domestic productivity and employment. 


\section{References}

Acs, Z., \& Varga, A. (2005). Entrepreneurship, agglomeration and technological change. Small Business Economics, 24, 323-334. http://dx.doi.org/10.1007/s11187-005-1998-4

Acs, Z., Audretsch, D., Braunerhjelm, P., \& Carlsson, B. (2004). The missing link: The knowledge filter, entrepreneurship and endogenous growth. Working Paper, Centre for Economic Policy Research, London.

Audretsch, D., \& Keilbach. M. (2004). Entrepreneurship and Regional Growth: An Evolutionary Interpretation. Journal of Evolutionary Economics, 14(5), 605-616. http://dx.doi.org/10.1007/s00191-004-0228-6

Cole, A.H. (1968). Meso-economics: A contribution from entrepreneurial history. Explorations in Entrepreneurial History, 6(1), 3-33.

Employment Institute of the General Confederation of Greek Workers. (2012). Greek Economy and Employment. Yearly Report 2011, Athens.

Eurostat Structural Business Statistics Database. (2012). Retrieved from http://epp.eurostat.ec.europa.eu

Evans, D., \& Leighton, L. (1989). Some Empirical Aspects of Entrepreneurship. American Economic Review, 79, 519-535.

Gartner, W.B. (1985). A conceptual framework for describing the phenomenon of new venture creation. Academy of Management Review, 10(4), 696-706.

Global Entrepreneurship Monitor Database. (2012). Retrieved from http://www.gemconsortium.org

Hebert, R., \& Link A. (1988). The Entrepreneur. Praeger Publ, New York.

Henderson, J. (2002). Building the Rural Economy with High-Growth Entrepreneurs. Federal Reserve Bank of Kansas City Economic Review, 87(3), 45-70.

Holcombe, R. (1998). Entrepreneurship and Economic Growth. The Quarterly Journal of Austrian Economics, 1, 45-62. http://dx.doi.org/10.1007/s12113-998-1008-1

Holmes, T.J., \& Schmitz, J.A. (1990). A Theory of Entrepreneurship and its Application to the Study of Business Transfers. Journal of Political Economy, 2, 265-94. http://dx.doi.org/10.1086/261678

Kirzner, I. (1973). Competition and entrepreneurship. The University of Chicago Press.

Knight, F. (1921). Risk, uncertainty, and profit. Houghton Mifflin, Boston.

Kreft, S., \& Sobel, R., (2005). Public Policy, Entrepreneurship, and Economic Freedom. Cato Journal, 25(3), 595-616.

Leibenstein, H. (1978). General X-efficiency and economic development. Oxford University Press. 


\section{Macrothink}

Research in Applied Economics

ISSN 1948-5433

2013, Vol. 5, No. 1

Low, M., \& MacMillan I. (1988). Entrepreneurship: Past Research and Future Challenges. Journal of Management, 139-161. http://dx.doi.org/10.1177/014920638801400202

Lumpkin, T., \& Dess, G. G. (1996). Clarifying the Entrepreneurial Orientation Construct and Linking it to Performance. Academy of Management Review, 21, 135-172.

Minniti, M. (1999). Entrepreneurial Activity and Economic Growth. Global Business and Economics Review, 1, 31-42. http://dx.doi.org/10.1504/GBER.1999.006134

National Confederation of Greek Trade. (2011). Yearly Report on Greek Trade. Athens.

Organization for Economic Cooperation and Development. (2011). Entrepreneurship at a Glance. OECD Publishing.

Porter, M. E. (1990). The competitive advantage of nations. Macmillan, New York.

Reynolds, P., Hay, M., \& Camp, S.M. (1999). Global Entrepreneurship Monitor. Kansas City, Missouri: Kauffman Center for Entrepreneurial Leadership.

Romer, P. (1986). Increasing Returns and Long Run Growth. Journal of Political Economy, 94, 1002-1037. http://dx.doi.org/10.1086/261420

Schmitz. Jr., \& James A. (1989). Imitation, Entrepreneurship, and Long-Run Growth. The Journal of Political Economy, 97(3), 721-739. http://dx.doi.org/10.1086/261624

Schumpeter, J. A. (1934). The Theory of Economic Development. Harvard University Press, Cambridge.

Smith, D. (2010). The Role of Entrepreneurship in Economic Growth. Undergraduate Economic Review, 6(1), Art. 7.

Stevenson, H., Roberts, M., \& Grousback H. (1985). New business ventures \& the entrepreneur. Homewood, Irwin.

Wennekers, A. R. M., \& Thurik, A. R. (1999). Linking entrepreneurship and economic growth. Small Business Economics, 27-55. http://dx.doi.org/10.1023/A:1008063200484

Wong, P, Ho Y., \& Autio E. (2005). Entrepreneurship, Innovation and Economic Growth: Evidence from GEM Data. Small Business Economics, 24, 335-350. http://dx.doi.org/10.1007/s11187-005-2000-1

World Bank. (2008). Doing Business. Retrieved from http://www.doingbusiness.org

World Bank. (2010). Doing Business. Retrieved from http://www.doingbusiness.org

World Bank. (2012). Doing Business. Retrieved from http://www.doingbusiness.org

World Economic Forum. (2010). The Global Competitiveness Report 2010-2011 
Note

Note 1. In the year 2007 the population count was Germany: $82.2 \mathrm{~m}$. France: $63.7 \mathrm{~m}$. UK: 61.1 m. Greece: $11.1 \mathrm{~m}$. Portugal: $10.6 \mathrm{~m}$. Sweden: $9.1 \mathrm{~m}$ and Spain: 45.2 million.

\section{Copyright Disclaimer}

Copyright reserved by the author(s).

This article is an open-access article distributed under the terms and conditions of the Creative Commons Attribution license (http://creativecommons.org/licenses/by/3.0/). 